\title{
Job Satisfaction and Occupational Stress among Public and Private Bank Employees
}

\author{
Dr. Karshan B. Chothani ${ }^{1}$

\section{ABSTRACT:}

This article discusses the emerging research concerned with the effect job satisfaction on occupational stress experienced among bank employees. The Occupational Stress Index developed by A.K. Srivastava and A. P. Singh (1984) and Job Satisfaction scale (JSS) developed by Dr. Amar Singh and Dr. T R Sharma (2007) by the researchers to importune information from bank employees was administered to 100 respondents comprising of both public and private banks in the branches of SBI, Bank of Baroda, Punjab National Bank, Co-Operative Bank, ICICI, HDFC and Axis Bank within Ahmedabad city. Objectives of the studies are 1) To study the level of Job Satisfaction of Employees working in Private and Public bank in relation to types of Bank and Gender. 2) To study the Occupational Stress of Employees working in Private and Public bank in relation to types of Bank and Gender. 3) To know the correlation between Job Satisfaction and Occupational Stress of Private and public Bank employees. Statistical 't'-test and correlation were used for data analysis. The findings of the study reflect that Public Bank employees are more satisfied with their jobs and occupationally less stressed than the Private bank employees. Further Female bank employees are less satisfied and under higher level of occupational stress as compared to their Male bank employees counterparts. Whereas, there is a negative \& significant co-relation between Job Satisfaction \& Occupational stress of Bank employees. It is suggested from findings of the study, that in order to reduce occupational stress among Private bank employees, the job satisfaction must be enhanced.

Keywords: occupational stress, job satisfaction, Public and Private Banks and Gender.

\section{INTRODUCTION:}

India is a vast country. It is peculiar for its unique nature in its diverse culture and atmosphere. India's diversity is visible in its social and economic set up. Banks plays a vital role in the country's economy. Our banking system has witnessed various alterations and policy modifications which have revolutionaries the present day banking scenario. These modifications have laid strong foundation for the current level improvised banking solutions. In every organizations, employees are facing increasing pressures in trying to be effective at work.

\footnotetext{
${ }^{1}$ Associate Professor \& Head, Department of Psychology, C. U. Shah Arts College, Ahmedabad, Gujarat.

Editor, IJIP
} 
Modern business demands high quality performance, short response times, long working hours and heavy workloads. When an employee has a problem, whether the origin is work, performance in the work place is likely to be affected. It makes sense, therefore, to take the best care of employees and their psychological needs.

Job satisfaction is defined as all the feelings that an individual has about his/her job (Sowmya and Panchanatham, 2011). Job satisfaction is associated with increased output, efficiency of the organization, loyalty with the organization, and reduced absenteeism and earnings (Ellickson \& Logsdon, 2001; Wright \& Davis, 2003), however, if employees are not satisfied with the job then it may cause turnover intentions, increasing costs, decreasing profits and ultimately customer unhappiness with the organization (Zeffane et al., 2008).Over years, an attempt has been made to categorize and find out the factors that affect job satisfaction and found wages as the main factor for job satisfaction, but other factors such as the promotion, recognition of work, and employees loyalty arealso considered important ( as cited in Salem et al., 2013).Nevertheless, Calisir et al., (2010) asserts that salaries and incentives are the most important determinant of job satisfaction. Job satisfaction is an attitude or emotional response to work task as well as to the physical and social conditions of the work place and Job Stress is one of the determinants which may affect the job satisfaction of an employee(Jagtap \& Yadav, 2014).Stress causes a reduction in the effectiveness of the organisation, high desertion rates, low morale, and low job satisfaction (Jimmieseon, Terry \&Callan, 2004).In occupational stress model, it was found that job stress and job satisfaction are distinct, but highly interrelated variables. According to Seaward's (2005) findings, the ability of employees to properly control and manage their job stress will lead to have higher job satisfaction.

Occupational stress occurs in situations in which discrepancies exist between occupational demands and opportunities on the one hand and the workers capacities needs and expectations on the other hand. Occupational stress is a stress reaction, which is both physiological, and psychological. In present times it has been strongly felt that teaching has become a very stressful profession. For Employees the sources of stress are generally the heavy workload, time pressure, poor working environment, time pressure, lack of recognition for work, delayed salaries, etc. Stress up to moderate level is helpful for the motivation but stress above the moderate level affects the physical and mental wellbeing of the Employees.

The present paper aims to delve deeper to explore the mean differences and co-relationship exist between job satisfaction and occupational stress amongst public and private bank employees.

\section{REVIEW OF LITERATURE}

Sattar and Ali (2014) measures the factors affecting the employee satisfaction by discussing variables such as promotion, work environment, leadership and job satisfaction and observe its impact on workers of the banking industry at Bahawalpur district. It was determined that all the 
variables promotions, work environment, leadership behaviour and job satisfaction have significant relationship with employees job satisfaction.

Salem et al., (2013), concludes that most people or employees agreed that personality type suits the work they do, and have the opportunity to do what they do best and they are also optimistic about their personal and professional life and further demonstrates that fair policy of recruitment and selection leads to employee satisfaction at work.

Presence of higher degree of occupational stress adversely affected the level of job satisfaction and if employees are allottted low burden of tasks, targets and operational activities to perform for their customers than they'll become more calm, happy and satisfied with their jobs instead of having hectic workload, burden and tension created by the line managers as well as customers (Khan, Ramzan \& Butt, 2013).

After extensive literature review, Sowmya and Panchanatham (2011)reveals that job satisfaction is dependent on supervisor behavior, coworker behaviour, pay and promotion, job and working condition and organizational aspects. In the case of job satisfaction aspects, commercial banks employee perceived pay and promotion as an indispensible factor to decide their satisfaction level.

The level of employees' job satisfaction increases by many factors and when employees are satisfied with their work, they feel motivated ( Noor, 2011). The demand of employees work life balance is increased by change in trends in the business such as change in organizations structure, diversity of work force and female employees working in organizations. Organizations should provide work life balance facilities to their employees so that employees can perform their duties effectively and leads organization to the success.

Kamal and Debashish (2009) found that with the change of satisfaction determinants, level of job satisfaction also varies. They observed that as a person ages, his job satisfaction shows an increasing trend. With age,spiritualism of the person increases, but his alternatives for change decreases. Younger employees have more energy, more expectations and more options, and hence have lesser satisfaction with the job.

\section{OBJECTIVES :}

The Objectives of the study are stated as follows

1. To study the level of Job Satisfaction of employees working in public bank and private bank in relation to types of Bank and Gender.

2. To study the Occupational Stress of employees working in public bank and private bank in relation to types of Bank and Gender.

3. To know the correlation between Job Satisfaction and Occupational Stress of Public bank and Private bank employees. 
Job Satisfaction and Occupational Stress among Public and Private Bank Employees

\section{HYPOTHESIS :}

1. There is no significant difference between public bank and private bank employees in respect of their job satisfaction.

2. There is no significant difference between public bank and private bank employees in respect of their occupational stress.

3. There is no significant difference between Male and Female bank employees in respect of their job satisfaction.

4. There is no significant difference between Male and Female bank employees in respect of their occupational stress.

5. There is no significant relationship between job satisfaction and occupational stress.

\section{METHODOLOGY}

\section{Participant:}

A sample of 100 Employees was randomly selected from Public banks and Private banks (50 were Public bank employees and 50 Private bank employees) of Ahmedabad city of Gujarat.

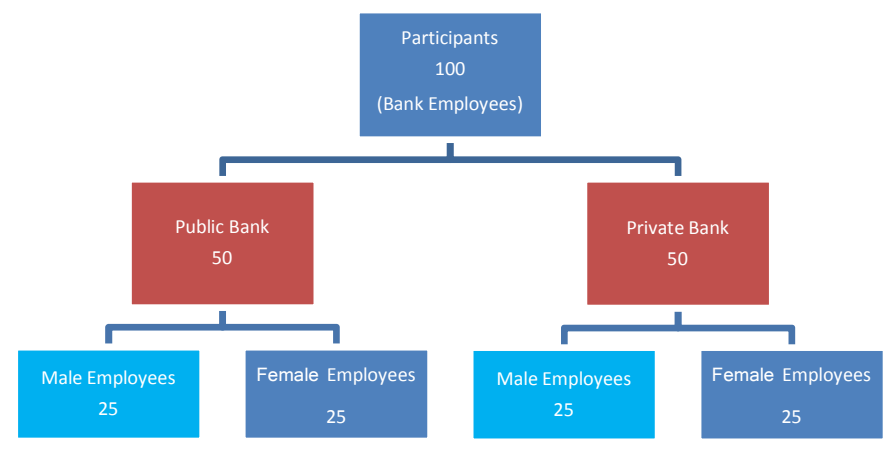

\section{Variables Involved :}

In the present study, job satisfaction and occupational stress have been taken as the dependent variables, whereas demographic variables such as types of Bank, Gender constituted the independent variables.

\begin{tabular}{|c|c|c|c|c|}
\hline No. & Variable & Type of variable & Level & Name of the level \\
\hline 1 & Types of Bank & Independent & 2 & Public Bank, Private Bank \\
\hline 2 & Gender & Independent & 2 & Male, Female \\
\hline 3 & Job Satisfaction & Dependent & 1 & Score of Job Satisfaction Scale \\
\hline 4 & $\begin{array}{c}\text { Occupational } \\
\text { Stress }\end{array}$ & Dependent & 1 & Score of Occupational Stress Index \\
\hline
\end{tabular}




\section{Tools of the study:}

Occupational stress was assessed using "Occupational Stress Index OSI" (Srivastava and Singh, 1984). The questionnaire is consisted of 46 statements with five alternative responses e.g., 5 for strongly agree, 4 for mildly agree 3 agree, 2 for disagree and 1 for strongly disagree. Responses were obtained on a summated rating scale format ranging from "strongly agree" to "strongly disagree". Total score on this scale is considered for the assessment of occupational stress. Higher scores indicated higher perceived occupational stress or more the score on this scale indicates more stress.

The job satisfaction scale (JSS) developed by Singh \& Sharma (2007) will be used to measure job satisfaction among the sample Bank Employees. The scale has a very wide acceptance in measuring psychological aspects of functioning in any profession. It consisted of 80 statements in the pilot study. After try out only 30 statements were retained in the final. The scale has been standardized on engineers, doctors and teachers. The test retest reliability of the scale works out to be .978 .

\section{RESULTS AND DISCUSSION:}

To find the meaningful interpretation of the raw scores, the data is analysed using Mean, S.D and 't'-test.

Ho1. There is no significant difference between public bank and private bank employees in respect of their job satisfaction.

Table-1: Mean, SD and 't' value of job satisfaction scores of Public Bank Employees and Private Bank Employees.

\begin{tabular}{|c|c|c|c|c|}
\hline \multirow{2}{*}{ Types of Bank } & \multicolumn{3}{|c|}{ Job satisfaction } & \multirow{2}{*}{ ' $t$ ' } \\
\cline { 2 - 4 } & N & M & SD & \\
\hline Public Bank & 50 & 78.02 & 4.60 & \multirow{2}{*}{$8.27^{* *}$} \\
\hline Private Bank & 50 & 67.78 & 7.45 & \\
\hline
\end{tabular}

*Significant at .01 levels. (2.63)

Table no.1 the ' $t$ ' test has been applied to find out whether there is any significant difference in the job satisfaction with respects to their Bank types. The calculated ' $t$ ' value is found to be 8.27 which is greater than the table value and significant at 0.01 level. Hence the Null Hypothesis "There is no significant difference between public bank and private bank 
employees in respect of their job satisfaction" is rejected. Therefore it is concluded that there is a significant difference between public bank and private bank employees in the job satisfaction. This result indicates that the mean scores for the variable of job satisfaction for Public Bank Employees were 78.02 and Private Bank Employees were 67.78 respectively. The mean value indicates that the Public Bank Employees scored better than the Private Bank Employees in the job satisfaction. It means that the Public Bank Employees were more satisfied with their job than the Private Bank Employees. The main reasons for job dissatisfaction in Private bank were job insecurity, salary not at par with experience, not much value or credit was given for the tasks accomplished and monotonous nature of job.

Ho2. There is no significant difference between public bank and private bank employees in respect of their occupational stress.

Table-2: Mean, SD and t value of occupational stress scores of Public Bank Employees and Private Bank Employees.

\begin{tabular}{|c|c|c|c|c|}
\hline \multirow{2}{*}{ Types of Bank } & \multicolumn{3}{|c|}{ Occupational stress } & \multirow{2}{*}{ ' $t$ ' } \\
\cline { 2 - 4 } & N & M & SD & \\
\hline Public Bank & 50 & 101.68 & 16.15 & \multirow{2}{*}{$5.05^{*}$} \\
\hline Private Bank & 50 & 118.94 & 17.98 & \\
\hline
\end{tabular}

*Significant at .01 levels. (2.63)

The table no.2 indicates the significant difference between the Public Bank Employees and Private Bank Employees in respect of their level of occupational stress. The table no.2 indicates that the Private Bank Employees have high mean score (118.94) in relation to occupational stress compared to Public Bank Employees (101.68) in this particular research. The t-value was 5.05, significant at 0.01 level of confidence. The mean score was higher for private sector bank employees indicating that private bank employees have high occupational stress than public bank employees.

The results of the present study are in agreement with the findings of research studies conducted by Sadat Ali, Al-Habdan and Shriyan (2005) and Kumar (2008). Their findings revealed significant difference in the level of occupational stress between Public and Private bank employees. The employees working in Public Banks were found to fare better than those in Private Banks. The possible reason for the present findings could be that the employees working in Private Banks have longer working hours as compared to their counterparts working in Public Banks. Private bank employees undergo high occupational stress as they work in late nights, 
conduct more market oriented activities than public bank employees and also they are driven by targets.

The finding of the present study would provide useful insight to policy makers in public and Private Banks. The findings can help them to take suitable measures and actions to help employees to distress them which can help in increasing output and employees stability in their respective banks.

Ho3 There is no significant difference between Male and Female bank employees in respect of their job satisfaction.

Table-3: Mean, SD and $t$ value of job satisfaction scores of Male and Female Bank Employees.

\begin{tabular}{|c|c|c|c|c|}
\hline \multirow{2}{*}{ Gender } & \multicolumn{3}{|c|}{ Job satisfaction } & \multirow{2}{*}{ ' $t$ ' } \\
\cline { 2 - 4 } & $\mathbf{N}$ & $\mathbf{M}$ & SD & \\
\hline Male Bank Employees & 50 & 74.54 & 5.70 & \multirow{2}{*}{$2.07 * *$} \\
\hline Female Bank Employees & 50 & 71.26 & 9.61 & \\
\hline
\end{tabular}

**Significant at .05 levels. (1.98)

Table no. 3 the ' $t$ ' test has been applied to find out whether there is any significant difference in the job satisfaction with respects to their Gender. The calculated ' $t$ ' value is found to be 2.07 which is greater than the table value and significant at 0.05 level. Hence the Null Hypothesis "There is no significant difference between Male and Female bank employees in respect of their job satisfaction" is rejected. Therefore it is concluded that there is a significant difference between Male and Female bank employees in the job satisfaction. This result indicates that the mean scores for the variable of job satisfaction for Male Bank Employees were 74.54 and Female Bank Employees were 71.26 respectively. The mean value indicates that the Male Bank Employees scored better than the Female Bank Employees in the job satisfaction. It means that the Male Bank Employees were more satisfied with their job than the Female Bank Employees. 
Ho4 - There is no significant difference between Male and Female bank employees in respect of their occupational stress.

Table-4: Mean, SD and ' $t$ ' value of occupational stress scores of Male and Female Bank Employees

\begin{tabular}{|c|c|c|c|c|}
\hline \multirow{2}{*}{ Gender } & \multicolumn{3}{|c|}{ Occupational stress } & \multirow{2}{*}{ 't' } \\
\cline { 2 - 4 } & N & M & SD & \\
\hline Male Bank Employees & 50 & 104.54 & 23.92 & \\
\hline Female Bank Employees & 50 & 116.08 & 9.78 & $3.16^{*}$ \\
\hline
\end{tabular}

*Significant at .01 levels. (2.63)

The table no. 4 indicates the significant difference between the Male and Female Bank Employees in their level of occupational stress. The calculated ' $t$ ' - value is found to be 3.16, which is greater than the table value and significant at 0.01 level. Hence the Null Hypothesis "There is no significant difference between Male and Female bank employees in respect of their Occupational Stress" is rejected. Therefore it is concluded that there is a significant difference between Male and Female bank employees in the Occupational Stress. This result indicates that the Female Bank Employees have high mean score (116.08) in relation to occupational stress compared to Male Bank Employees (104.54) in this particular research. This shows Female Bank Employees high level occupational stress compared to Male Bank Employees.

Ho5 - There is no significant relationship between job satisfaction and occupational stress.

Table - 5: Showing the Correlation between job satisfaction and occupational stress

\begin{tabular}{|c|c|c|c|c|}
\hline Sr. No. & Variables & N & Mean & 'r value \\
\hline 1 & Job Satisfaction & 100 & 72.90 & \multirow{2}{*}{$-0.225^{* *}$} \\
\hline 2 & Occupational stress & 100 & 110.31 & \\
\hline
\end{tabular}

**Significant at 0.05 level.

As evident from Table 5, the coefficient of correlation (r) between job satisfaction and occupational stress of Bank Employees for the total sample $(\mathrm{N}=100)$ studied were negative and significant at 0.05 level. Therefore, the two variables are functionally related i.e., the variables exhibit a relationship thereby indicating that any increase in occupational stress will be attended 
by a corresponding decrease in job satisfaction and vise versa. This indicates that occupational stress does have negative impact on the job satisfaction of Bank Employees. Hence, hypothesis 5 is rejected.

\section{SUMMARY OF THE FINDINGS}

- Public Bank Employees and Private Bank Employees differ significantly in their job satisfaction. Public Bank Employees have high level of job satisfaction than Private Bank Employees.

- Public Bank Employees and Private Bank Employees differ significantly in their occupational stress. Private Bank Employees have high level of occupational stress than Public Bank Employees.

- Male and Female Bank Employees differ significantly in their job satisfaction. Male Bank Employees have high level of job satisfaction than Female Bank Employees.

- Male and Female Bank Employees differ significantly in their occupational stress. Female Bank Employees have high level of occupational stress than Male Bank Employees.

- Negative and Significant Correlation between job satisfaction and occupational stress of Bank Employees

\section{CONCLUSION}

In this research, the investigator has studied about the job satisfaction and occupational stress among Public and Private Bank Employees. Human beings have various biological, psychological and social needs, when these needs are not promptly and easily satisfied by them, an individual faces a condition of stress. It may be said that some drastic changes need to be made with regard to the Banking profession. So the work load of Employees may reduce. A good Employee should have commitment to Clients, Co-workers, society and Bank management. Higher pay packages and perks and less rigidity along with improved work atmosphere so that the younger generation starts considering Banking profession as a serious option.

\section{REFERENCES}

Brewer,E and Lander,J.M. (2003): The Relationship between Job Stress and Job Satisfaction Among industrial and Technical.

Jagtap, U. R., \&Yadav, P. (2014). Impact of Job Stress on Job Satisfaction at SBI-Indore: With special reference to Non Managerial Employees. Sinhgad Institute of Management and Computer Application, 328-332.

Jimmieson, N. L., Terry, D. J., Callan, V.J. (2004). A longitudinal study of employee adaptation to organizational change: The role change- related information and change-related selfefficacy. J Occupat Health Psych, 9, 11-27.

Kamal, R., \&Debashish, S. (2009). A Study of Job Satisfaction of Bank Officers.Prajnan, 37,3.

Khan, A., Ramzan, M., \& Butt, M. S. (2013). Is job satisfaction of Islamic banks operational staff determined through organizational climate, occupational stress, age and gender. Journal of Business Studies Quarterly, 4, (3), 14-36. 
Kumar (2008). Occupational Stress of Bank Employees of Nationalized and Non-Nationalized Banks in Kerela. Research and Practice in Human Resource Management, 9(2), 109-118.

SabaSaleem, SadiaMajeed, Tariq Aziz, Muhammad Usman. (2013). determinants of job satisfaction among employees of banking industry at Bahawalpur.Journal of Emerging Issues in Economics, Financeand Banking, 1, (2), 150-162.

Sadat-Ali, M., Al-Habdan and Shriyan, D. (2005). Are Bank employees prone to burnout? Saudi Medical Journal, 28(8), 1180-1182.

Sattar, S., \& Ali, N. (2014).Level of job satisfaction among employees of banking industries at Bahawalpur.Developing Country Studies, 4, (3), 1-6.

Seaward, B. L. (2005).Managing Stress: principals and Strategies for Health \& well - being. Massachusetts: Jones \& Bartlett Publishers.

Singh, Amar \& Sharma, T.R. (2007). Manual of the Job Satisfaction Scale (JSS). National Psychological Corporation, Agara:KacheriGhat, India.

Sowmya, K. R., \&Panchanatham, N. Factors influencing job satisfaction of banking sector employees in Chennai, India. Journal of Law and Conflict Resolution, 3, (5), 76-79. Retrieved from http://www.academicjournals.org/JLCR

Srivastava, A.K. \& Singh, A.P. (1984 ). Manual of the Occupational Stress Index. Department of Psychology, Banaras University, Varanasi.

Wright, B. E \&., Davis, B. S. (2003). Job satisfaction in the public sector: the role of the work environment. The American Review of Public Administration, 33, 170-90.

Zeffane, R., Ibrahim, M. E., \&Mehairi, R. A. (2008).Exploring the differential impact of job satisfaction on employee attendance and conduct: The case of a utility company in the United Arab Emirates.Employee Relations, 30, 3, 237-250. 